\title{
PRODUCTION OF FISH SAUCE FROM LOW COST SMALL FRESHWATER FISH AND THEIR QUALITATIVE EVALUATION
}

\author{
M. Faisal1*, M. N. Islam, M. Kamal and M. N. A. Khan ${ }^{1}$ \\ Department of Fisheries Technology, Bangladesh Agricultural University \\ Mymensingh-2202, Bangladesh
}

\begin{abstract}
The study was conducted to produce fish sauce from small freshwater fishes like Kholisa (Colisa fasciatus), Tit punti (Puntius ticto), Jat punti (Puntius sophore), Tengra (Mystus vittatus), Taki (Channa punctatus), Gutum (Lepidocephalichthys guntea), Guchi (Macrognathus pancalus), Veda (Nandus nandus), and Bujuri (Mystus tengara) by using different concentrations of salt $(25 \%$ as Treatment-I, $30 \%$ as Treatment-II and $35 \%$ as Treatment-III). Fishes were fermented for 9 months by the combined action of microorganisms and enzymes present in fish tissue and viscera in presence of salt. During fermentation the initial protein content in fish was 15.17\% which were nearly digested and liquefied at the end of fermentation. Crude protein content on the basis of total nitrogen were found to be $14.58,13.88$ and $12.63 \%$ in Treatment-I, II and III respectively while the highest ash content in fish sauce was $22.97 \%$ in Treatment-III. Initial Total Volatile Base Nitrogen in fish was 1.92 $\mathrm{mg} / 100 \mathrm{~g}$, which reached 20.88, 20.52 and $20.31 \mathrm{mg} / 100 \mathrm{~g}$ respectively in three treatments. Initial aerobic plate count (APC) in fish was $5.99 \times 10^{6} \mathrm{cfu} / \mathrm{g}$ and after fermentation and 15 days of aging the APC in fish sauce was reduced to $1.53 \times 10^{4}$ $\mathrm{cfu} / \mathrm{ml}$ in Treatment-I, $1.40 \times 10^{4} \mathrm{cfu} / \mathrm{ml}$ in Treatment-II and $1.27 \times 10^{4} \mathrm{cfu} / \mathrm{ml}$ in treatment-III. The major bacterial groups identified in fish sauce were Bacillus, Micrococcus, Lactobacillus and Pseudomonas. Considering the values of different parameters and result of panel test, fish sauce produced with $25 \%$ salt (Treatment-I) was found to be of best quality.
\end{abstract}

Key Words: Fish Sauce, Salt treatment, Fermentation

\section{INTRODUCTION}

Many fermented fish products are prepared in different parts of the world and the method of processing depends upon various factors, such as availability of raw materials, consumers' preference and climatic condition of the region (Al-Jedah et al., 2000). Traditional fermentation in developing countries is one of the oldest processing methods which are used for preserving fish, where it is not only extend the shelf life but also enhanced a unique taste, flavor and nutritional quality of end products (Anihouvi et al., 2006 and Nayeem et al., 2010). There are a number of fish fermentation products such as fish

\footnotetext{
${ }^{1}$ Department of Fishing \& Post Harvest Technology, Faculty of Fisheries, Chittagong Veterinary and Animal Sciences University, Chittagong, Bangladesh

*Corresponding author (Email: mdfaisal_bau@yahoo.com)
} 
sauce which are mainly prepared for flavor enhancers and condiments. Fish sauce is a product that can be made cheaply from various fish raw materials, which are not normally used for food fish. It is a brown, liquid seasoning commonly used in most parts of Southeast Asia. It is called by different names in different countries and it contains a mixture of amino acids and other protein degradation products (Gildberg, 2001; Fukami et al., 2002 and Ichimura et al., 2003). In Southeast Asia millions of liters of fish sauce are produced annually for daily consumption by at least 350 million people, which is prepared from both sea and freshwater fish. Almost every species of fish and even shellfish can be used as raw material (Beddows, 1979). All the fish sauce being sold in Bangladesh is imported and there is no report of producing fish sauce in Bangladesh. Many small fish species from both freshwater and marine water are underutilized or not utilized economically. Considering the above factors the present study was undertaken for the production of fish sauce using cheap local raw material and simple technology.

\section{MATERIALS AND METHODS}

The present study was conducted in the laboratory of Fisheries Technology Department, Bangladesh Agricultural University (BAU), Mymensingh. The samples which included Kholisa (Colisa fasciatus), Tit punti (Puntius ticto), Jat punti (Puntius sophore), Tengra (Mystus vittatus), Taki (Channa punctatus), Gutum (Lepidocephalichthys guntea), Guchi (Macrognathus pancalus), Veda (Nandus nandus), and Bujuri (Mystus tengara) were collected from KamalRanjit (KR) market of BAU, Mymensingh in fresh condition. All the fish samples were of small and non-commercial size.

\section{Preparation of fish sauce}

The collected fish samples were washed thoroughly with freshwater to remove all dirt, slime, and unwanted particles. Then the samples were weighed and divided into three parts ( $5 \mathrm{Kg}$ each), then mixed properly with three different concentration $(25 \%, 30 \%$ and $35 \%)$ of salt. A layer of salt was placed at the bottom of each plastic container, and then salt mixed fish were poured in it. Finally, a layer of salt was spread to cover the surface of the fishes. Plastic container with salted fish samples were covered with lids and kept in a dry place. After 7 days unsaturated brine solution was added to submerge the fish to prevent it from oxidation. Floating fishes on the surface of brine water were kept in submerged condition by placing a weight and allowed to ferment for 9 months. The chemical and bacteriological changes of the fish samples during fermentation were determined at 15 days intervals during this period. After 9 months the liquid part was extracted from the fermented fish samples, aged in the direct sunlight for 15 days, and filtered to separate the undigested portions. Thus the fish sauce became ready to use (Fig. 1).

\section{Analytical procedures}

All the representative fish species (fresh) were mixed together and ground in a sterile mechanical grinder to make a paste. This ground sample was used for all biochemical and bacteriological analysis. The moisture, crude protein, total lipid and ash contents were determined using standard methods (AOAC, 1995), Total Volatile Base Nitrogen (TVB-N, 
mg N/100g) was determined according to the methods given in Pearson (1976). For aerobic plate count (APC) of bacteria, $10 \mathrm{~g}$ of fish sample was transferred aseptically to $90 \mathrm{ml}$ of sterile $0.2 \%(\mathrm{w} / \mathrm{v})$ peptone water. Serial decimal dilutions in $0.2 \%$ peptone water were prepared and $0.1 \mathrm{ml}$ of appropriate dilutions was poured on selective agar plates and spread with sterile L shaped glass rod followed by incubation at $37^{\circ} \mathrm{C}$ for $48 \mathrm{hrs}(\mathrm{FAO}, 1979)$. Bacterial colonies developed were counted for the determination of standard plate cont as $\mathrm{cfu} / \mathrm{g}$ of sample. Isolation and identification of bacteria was done according to the method suggested in Cowan and Steel's Manual for the Identification of Medical Bacteria (Barrow and Felthham, 1993).

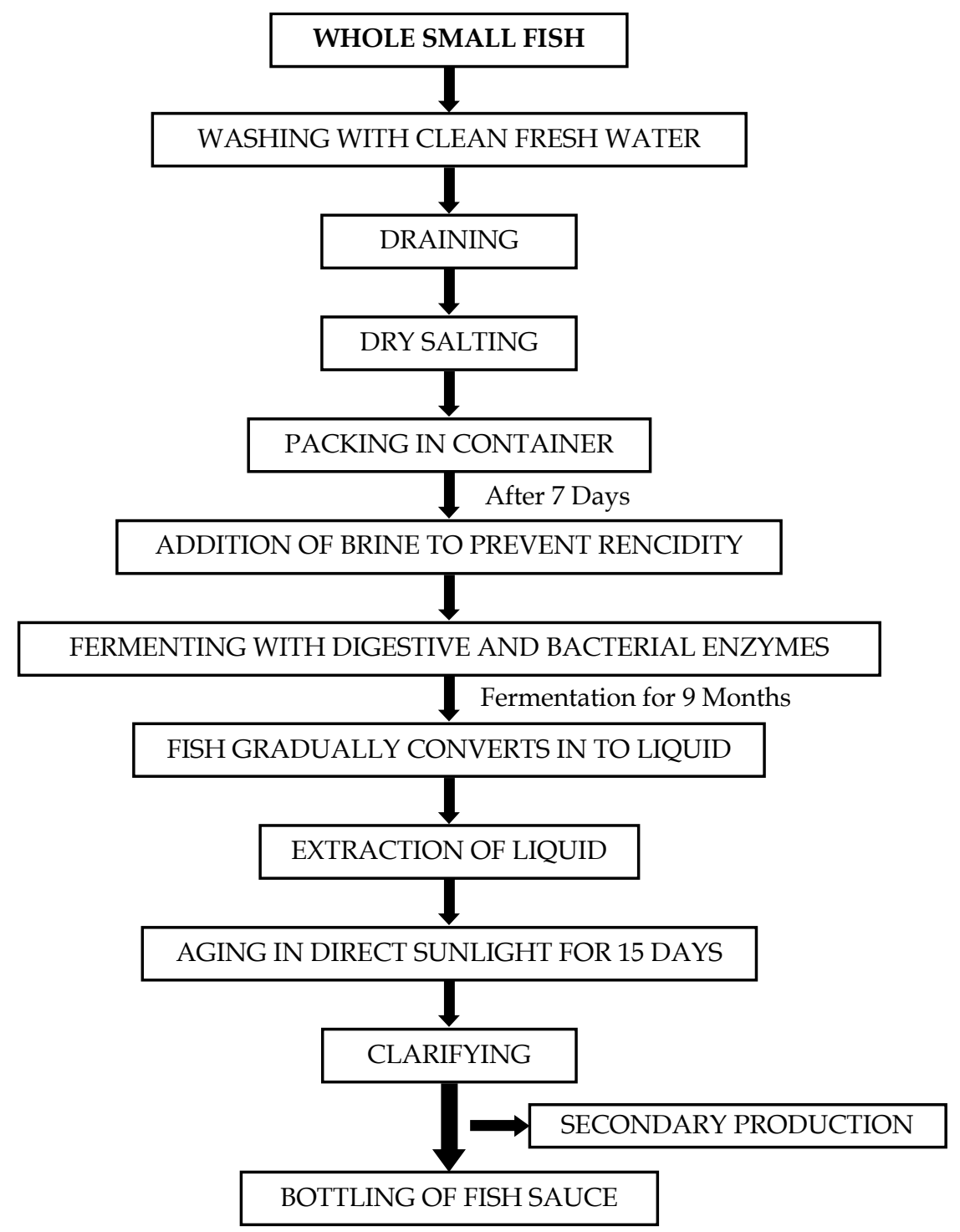

Fig. 1. Flow diagram of production of fish sauce 


\section{RESULTS AND DISCUSSION}

\section{Chemical and microbial analysis of fresh fish}

Proximate composition and bacterial load of fresh raw materials were determined and it was found that initial average moisture, total nitrogen content, crude protein, lipid and TVB-N contents in fish were $75.61 \%, 2.42 \%, 15.17 \%, 2.94 \% 1.918 \mathrm{mg} / 100 \mathrm{~g}$ respectively while initial APC was $5.99 \times 10^{6} \mathrm{cfu} / \mathrm{g}$. Major bacterial genera that identified from the fresh fish were Bacillus, Micrococcus, E. coli, Mycobacterium, Pseudomonas and Staphylococcus, among them Bacillus was dominant.

\section{Chemical and microbial changes during fermentation}

Salted fish samples were allowed to ferment for a period of 9 months. During fermentation process fish samples in 3 treatments became liquefied gradually due to combined action of salt and enzymes from fish and microorganisms. Changes in different parameters during fermentation process have been shown in Fig. 2 to 5.

Fig. 2 showing that initially total nitrogen content in fish was $2.43 \%$, after 24 hrs of addition of salt the total nitrogen content was dramatically increased and reached to $4.10 \%, 4.19 \%$ and $4.30 \%$ in treatment-I, treatment-II and treatment-III respectively due to reduction of moisture content and then gradually decreased with the progress of fermentation. At the same time the total nitrogen in brine increased gradually. The total nitrogen content in fish body was always lower in treatment-I than treatment-II and treatment-III. Similar results have been reported by Hjalmarsson et al. (2007) and Xu-Wei et al. (2008).

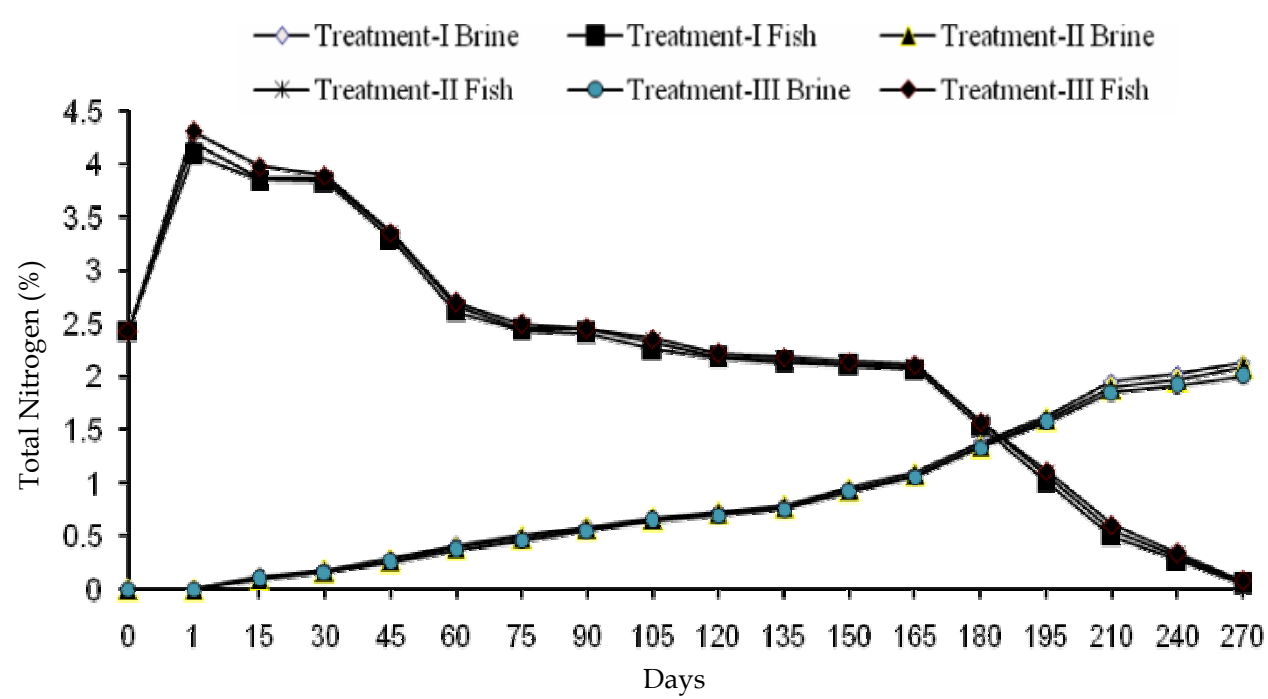

Fig. 2. Changes of total nitrogen content in salted fish and brine during fermentation

Changes in TVB-N in fish during fermentation have been shown in Fig. 3. TVB-N in fish body was initially $1.92 \mathrm{mg} / 100 \mathrm{~g}$. After addition of three different concentration of salt $(25 \%$, $30 \%$ and $35 \%$ ) the quick increase of TVB-N of fish body was retarded due to action of salt. 
With the progress of fermentation process protein in fish body gradually broke down and the amount of total volatile nitrogen increased and after 270 days the TVB-N reached the maximum level $19.93 \mathrm{mg} / 100 \mathrm{~g}$ in treatment-I, $19.69 \mathrm{mg} / 100 \mathrm{~g}$ in treatment-II and 19.07 $\mathrm{mg} / 100 \mathrm{~g}$ in treatment-III. Among the three different concentrations of salt, TVB-N was higher in treatment-I due to maximum break down of protein into nitrogenous compounds as because the enzymes in fish intestine and the microorganisms can tolerate comparatively lower concentration of salt. Similar result was found by Xu. Wei et al. (2008). Fish sauce was made from kilka fishes of the Caspian Sea (Iran) from 3 different preparations (whole kilka, cooked whole kilka and dressed kilka) the total volatile nitrogen was $25 \mathrm{mg} / 100 \mathrm{~g}$ after 6 months of fermentation (Moini and Koochekian, 2003).

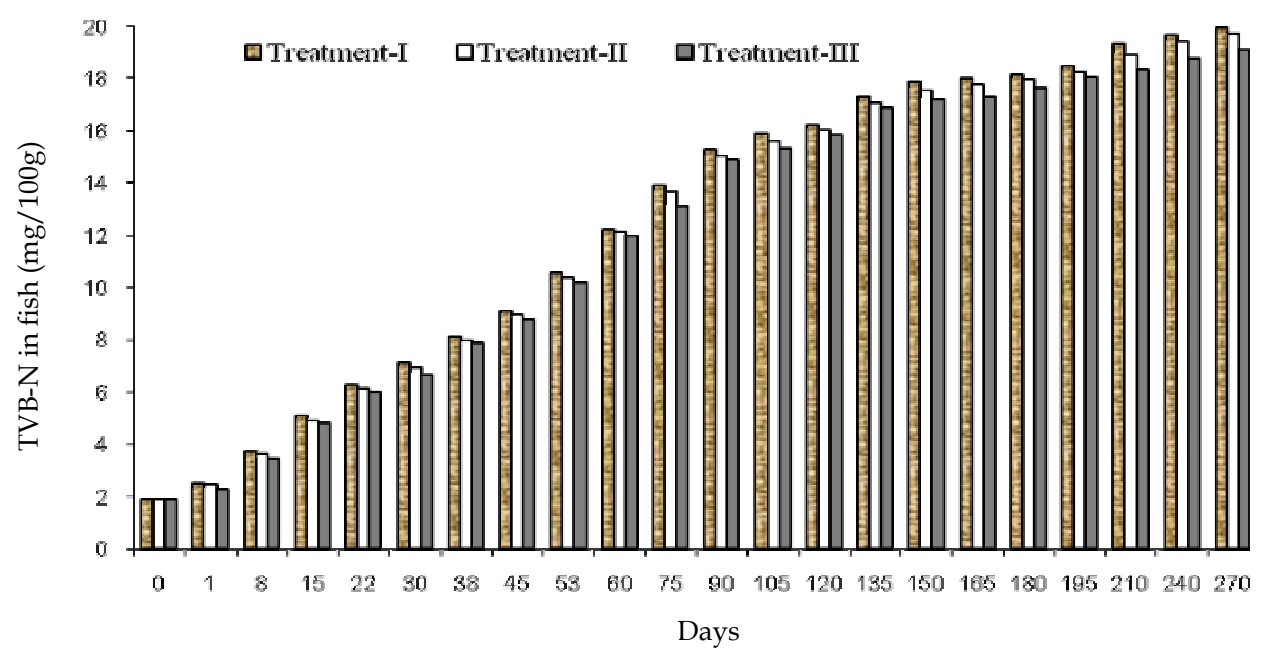

Fig. 3. Changes in Total Volatile Base Nitrogen (TVB-N) during fermentation

Initial moisture content of fish was $75.61 \%$ before addition of salt. After addition of salt the moisture content dramatically decreased due to entrance of salt in fish muscle. With the progress of fermentation process moisture level again started to increase and after 270 days the moisture content reached the maximum level, $73.29 \%, 72.04 \%$ and $69.98 \%$ for treatmentI, II and III respectively. These gradual increases in moisture level were happened in fish due to entrance of moisture in muscle and liquefaction of proteins. Kim et al. (1999) stated that the moisture content of anchovies and other small fishes varies from 46 to $77 \%$, during fermentation period. Result of the present study fall within this range.

Fig. 4 shows the total bacterial load in fish during fermentation. APC value was initially 5.99 $\times 10^{6} \mathrm{cfu} / \mathrm{g}$ but after $24 \mathrm{hrs}$ of addition of salt, the total bacterial load decreased to $3.38 \times 10^{5}$, $2.47 \times 10^{5}$ and $2.75 \times 10^{5} \mathrm{cfu} / \mathrm{g}$ in three treatments respectively. The total bacterial load gradually decreased, but on $8^{\text {th }}$ day the total bacterial load increased due to addition of brine solution to prevent rancidity. After 15 days the total bacterial load reached the lowest level and APC was $1.21 \times 10^{5}, 8.01 \times 10^{4}$ and $5.12 \times 10^{4} \mathrm{cfu} / \mathrm{g}$ in treatment- I, II and III respectively. As the time passed the protein in fish body gradually broken-down into amino acids and other nutritive compounds, as a result the bacterial population got more nutrients 
and started to multiply rapidly. After 270 days the total bacterial load was $1.41 \times 10^{7}, 1.34 \times$ $10^{7}$ and $1.25 \times 10^{7} \mathrm{cfu} / \mathrm{g}$ in treatment- I, II and III respectively.

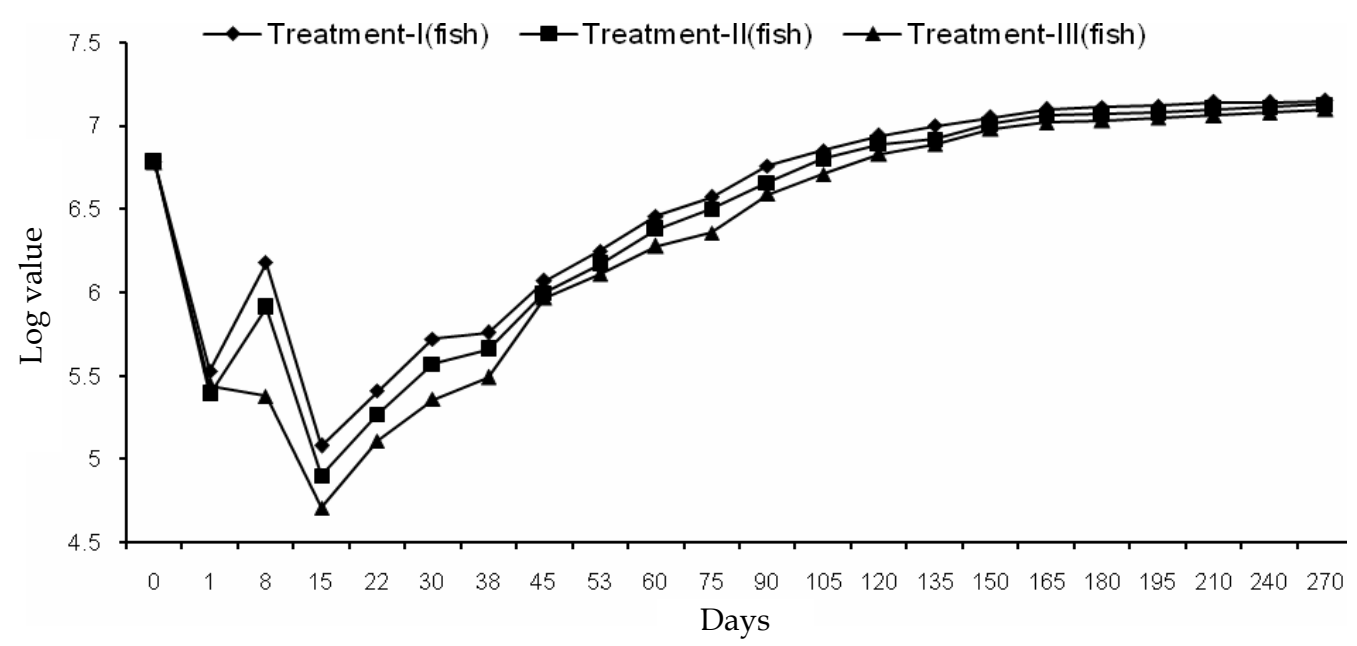

Fig. 4. Changes in bacterial load in fish during fermentation

Fig. 5 shows the changes in bacterial load in brine. On $7^{\text {th }}$ day brine was added to prevent oxidation of fish, after $24 \mathrm{hrs}$ of initial load of bacteria in brine solution counted $3.61 \times 10^{6}$ $\mathrm{cfu} / \mathrm{ml}$ in treatment-I, $5.55 \times 10^{5} \mathrm{cfu} / \mathrm{ml}$ in treatment-II and $3.04 \times 10^{5} \mathrm{cfu} / \mathrm{ml}$ in treatmentIII. The total bacterial load in brine quickly reduced and reached to the lowest level after 15 days. At $15^{\text {th }}$ day the bacterial load in brine sample was $6.29 \times 10^{4}, 3.20 \times 10^{4}$ and $1.29 \times 10^{4}$ $\mathrm{cfu} / \mathrm{ml}$ in three treatments respectively. After 270 days the total bacterial load reached the maximum levels that were $1.33 \times 10^{7}, 1.24 \times 10^{7}$ and $1.17 \times 10^{7} \mathrm{cfu} / \mathrm{ml}$ in treatment-I, II and III. Among three different concentrations of brine bacterial load was always higher in brine of treatment-I and lowest at the brine of treatment-III due to less survival rate and less enzyme activity at high concentration of salt.

Above results indicated that the addition of salt destroyed many types of bacteria except probably the halophilic and halotolerent ones. The remaining bacteria survived and gradually adjusted with the condition to multiply. Multiplication was accelerated due to breakdown of macromolecular compounds that released the low molecular weight compounds. These compounds served as nutrient source of the bacterial population. AlJedah et al. (2000) stated that the APC during preparation of fish sauce reached $1.8 \times 10^{7}$ $\mathrm{cfu} / \mathrm{ml}$ after 240 days of fermentation. Fish sauce was made from kilka fishes of the Caspian Sea (Iran) from 3 different preparations (whole kilka, cooked whole kilka and dressed kilka) the total bacterial count was 2.1 to $6.15 \log \mathrm{cfu} / \mathrm{ml}$ after 6 months of fermentation (Moini and Koochekian, 2003). The present study also agrees with the above reports. 


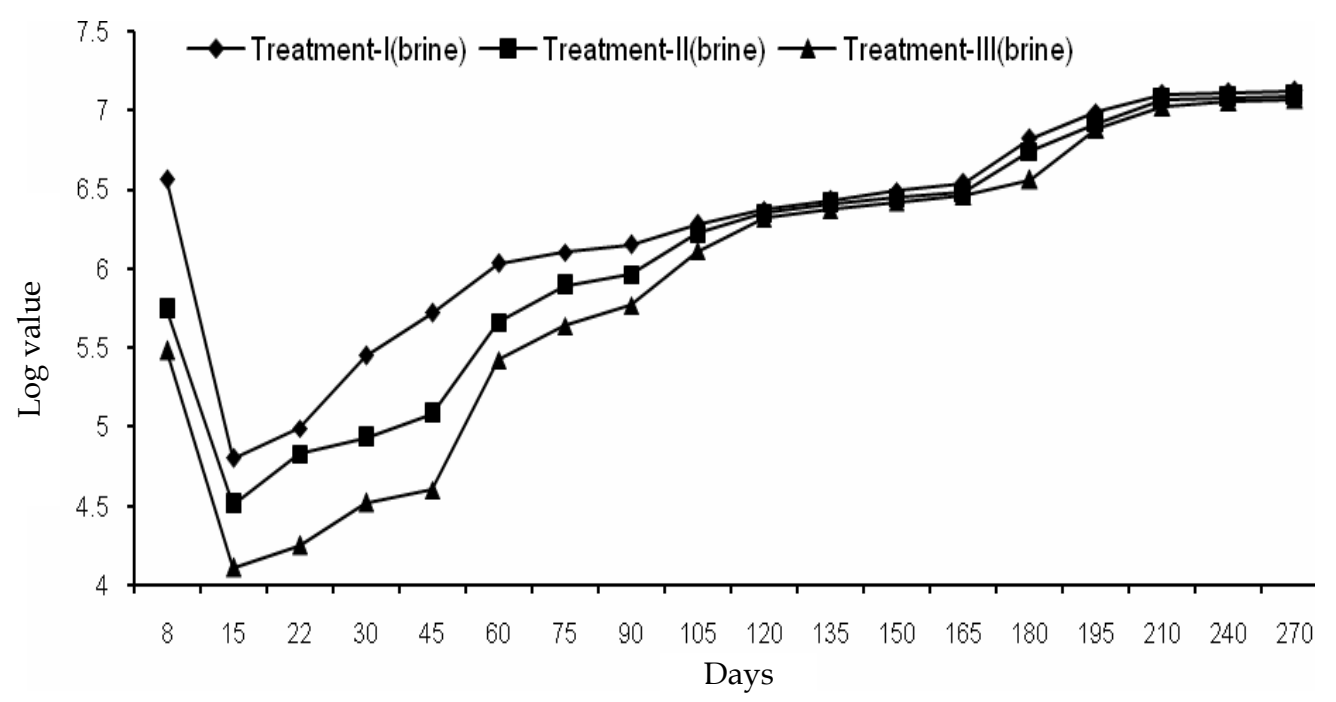

Fig. 5. Changes in Bacterial load in brine during fermentation

\section{Physical, chemical and microbial composition in final fish sauce (after aging in direct sunlight)}

After 9 months fishes in 3 treatments were fermented and liquefied completely, the liquid were collected and poured in the conical flask. The mouths of conical flasks were properly sealed with aluminum foil to prevent any kind of contamination. Those were kept in the direct sunlight for 15 days for aging. When aging was completed the upper layer of sauce became transparent but deep brown coloured and a layer of undigested fish body parts particularly scales and bones aggregated at the bottom of the flasks. The brown coloured liquid was separated from the undigested body parts of fish by using fine meshed filters. The filtered liquid was transferred in to other clean conical flasks and marked properly according to their treatments. In Table 1 physical properties of fish sauce in three different treatments is shown. Comparison of physical properties of fish sauce among the three treatments has shown that colour of sauce in treatment-I is comparatively darker than treatments II and III and that was judged as of best quality containing less salty that other two treatments. Table 2 shows the chemical and microbial properties sauce in three treatments. In Treatment-I protein and lipid content were higher than other two treatments. After 9 months of fermentation the bacterial load in three treatments were comparatively higher $\left(1.33 \times 10^{7}, 1.24 \times 10^{7}\right.$ and $1.17 \times 10^{7} \mathrm{cfu} / \mathrm{ml}$ in treatment-I, II and III respectively) but after 15 days of aging it dramatically reduced due to effect of UV ray of sunlight. Bacterial load in treatment-I was slightly higher $\left(1.53 \times 10^{4} \mathrm{cfu} / \mathrm{ml}\right)$ than treatment-II and III. Bacterial species identified were Bacillus, Micrococcus, Lactobacillus and Pseudomonas apparently no pathogen was present and hence safe for human consumption. 
Table 1. Physical properties of fish sauce

\begin{tabular}{l|c|c|c}
\hline Parameters & $\begin{array}{c}\text { Treatment-I } \\
\text { 25\% salt }\end{array}$ & $\begin{array}{c}\text { Treatment-II } \\
30 \% \text { salt }\end{array}$ & $\begin{array}{c}\text { Treatment-III } \\
35 \% \text { salt }\end{array}$ \\
\hline Colour & $\begin{array}{c}\text { Light brown coloured } \\
\text { liquid similar as world } \\
\text { class fish sauce } \\
\text { Flavour }\end{array}$ & $\begin{array}{c}\text { Comparatively deep brown } \\
\text { coloured than treatment-I }\end{array}$ & $\begin{array}{c}\text { Deep brown coloured than } \\
\text { treatment-II }\end{array}$ \\
Taste & Less Salty & Light fishy flavour & Light fishy flavour \\
Clearness & Clear & More salty & Highly salty \\
Liquidity & Liquid like water & Liquid like water & Clear \\
Acceptability & Highly acceptable & Acceptable & Liquid like water \\
\hline
\end{tabular}

Table 2. Chemical composition and microbial analysis of fish sauce

\begin{tabular}{l|c|c|c}
\hline \multicolumn{1}{c|}{ Parameters } & $\begin{array}{c}\text { Treatment-I } \\
(25 \% \text { Salt })\end{array}$ & $\begin{array}{c}\text { Treatment-II } \\
(30 \% \text { salt })\end{array}$ & $\begin{array}{c}\text { Treatment-III } \\
(35 \% \text { salt })\end{array}$ \\
\hline Protein (\%) & 12.28 & 11.88 & 11.63 \\
Total Nitrogen (\%) & 1.97 & 1.90 & 1.86 \\
Ash (\%) & 17.32 & 20.55 & 22.97 \\
Moisture (\%) & 67.44 & 64.79 & 62.70 \\
Lipid (\%) & 2.81 & 2.74 & 2.68 \\
Salt content (\%) & 23.89 & 28.94 & 34.63 \\
TVB-N (mg/100g) & 19.88 & 19.30 & 18.67 \\
Bacterial load in salted & $1.53 \times 104$ & $1.40 \times 10^{4}$ & $1.27 \times 10^{4}$ \\
agar medium (cfu/ml) & & & \\
Major bacterial species & Bacillus, Micrococcus, & Bacillus, Micrococcus, & Bacillus, Micrococcus, \\
& Lactobacillus and & Lactobacillus and & Lactobacillus and \\
& Pseudomonas & Pseudomonas & Pseudomonas \\
\hline
\end{tabular}

According to Hjalmarsson et al. (2007) total nitrogen content in the fish sauce from summer capelin was $2.03 \%$ after 250 days of fermentation. Kim et al. (2004) stated the moisture percentage of anchovies and other small fishes varies from 46 to $77 \%$, during fermentation period. Lopetcharat et al. (2002) mentioned that the ash content of Pacific whiting during preparation of fish sauce reached up to $25 \%$. Low salt fish sauce was prepared experimentally from squid processing by-products in three different manufacturing techniques and total protein in three fish sauce were $13.344 \%, 12.238 \%$ and $12.738 \%$, respectively (Xu-Wei et al, 2008). The ranges of protein content of these results during fermentation are quite similar with this study. Moini and Koochekian (2003) stated that the total volatile nitrogen was $25 \mathrm{mg} / 100 \mathrm{~g}$ after 6 months of fermentation of fish sauce, made from kilka fishes of the Caspian Sea (Iran). High-quality salmon sauce was developed with mature chum salmon (Oncorhynchus keta) samples, were eviscerated, deboned, washed, cut in small pieces, added 25\% salt and internal organs (Taniguchi and Takano, 2007). Fish 
sauce was made from kilka fishes of the Caspian Sea the total total bacterial count was 2.1 to $6.15 \log \mathrm{cfu} / \mathrm{ml}$ after 6 months of fermentation (Moini and Koochekian, 2003). Lopetcharat and Park (2002) stated that Staphylococcus, Bacillus and Micrococcus were found as predominant microorganisms during fermentation of fish sauce. Zaman et al. (2009) reported the presence of several microorganisms such as Enterobacteriaceae, Micrococci and Lactobacilli in fish sauce. The above discussion suggests that fish sauce prepared in this study was quite similar in qualitative aspects with fish sauce prepared elsewhere in the world. It is concluded that by simple salt treatment fermentation high quality fish sauce could be prepared from low priced non commercial fresh water fishes of Bangladesh.

\section{CONCLUSION}

Based on above discussion and considering the result of different parameters it can be concluded that fish sauce produced with $25 \%$ salt (Treatment-I) was found to be of best quality.

\section{REFERENCES}

Al-Jedah, J. H., Ali, M. Z. and Robinson, R. K. 2000. The inhibitory action of spices against pathogens that might be capable of growth in a fish sauce (mehiawah) from the Middle East. Int.J.-Food Microbiology., 57(1/2): 129-133.

Anihouvi, V. B., Saali, F., Sakyi- Dowsan, E., Ayenor, G. S. and Honhouigan, J. D. 2011. Response surface method for optimizing the fermentation condition during the processing of cassava fish (Pseudotolithus sp) into Lanhouin. Int. J. Eng. Sci. Technol. 3: 7085-7095.

A. O. A. C. 1995. Official Methods of Analysis, 16th ed. Association of Official Analytical Chemists International, Arlington, Virginia, USA.

Beddows, C. G., Ardeshir, A. G. and Daud, W. J. 1979. Biochemical changes occurring during the manufacture of Budu. J. Sci. Food and Agric., 30: 1097-1103.

Barrow, G, I and Feltham, R. K. A. 1993. Cowan and Steel's Manual for the Identification of Medical Bacteria. $3^{\text {rd }}$ ed. Cambridge University Press. pp. 1- 331.

FAO 1979. Manuals of food quality control, 4-Rev.1- Microbiological Analysis, Food and Agriculture Organization of the United Nations, Rome. pp. 14.

Fukami, K., Ishiyama, S., Yaguramaki, H., Masuzaw, T., Nabeta, Y., Endo, K. and Shimoda, M. 2002. Identification of distinctive volatile compounds in fish sauce. J. Agric. Food Chem., (50): 5412-5416.

Gildberg, A. 2001. Utilisation of male Arctic Capelin and Atlantic cod intestines for fish sauce productionevaluation of fermentation conditions. J. Biores. Technol., 76: 119-123.

Hjalmarsson, G. H., Park, J. W. and Kristbergsson, K. 2007. Seasonal effects on the physicochemical characteristics of fish sauce made from capelin (Mallotus villosus). J. Food Chem., 103(2): 495-504.

Ichimura, T., Hu, J., Quaaita, D. and Mayymas, S. 2003. Angoiotensin.1-Converting enzyme inhibitory activity and insulin secretion stimulative activity of fermented sauce. J. Bioscience and Bioengg., 96(5): 496-499. 
Kim, G. B., Im, Y. S., Lee, K. W., Cho, Y. J., and Choi, Y. J. 1999. Changes of components in saltfermented northern sand lance, Ammodytes personatus sauce during fermentation. J. Korean fisheries Society, 32(6): 693-698.

Lopetcharat, K. and Park, J. W. 2002. Characteristics of fish sauce made from Pacific whiting and surimi by-products during fermentation stage. J. Food Sci., 67(2): 511-516.

Moini, S. and Koochekian, A. 2003. Production of fish sauce from Caspian Sea kilka, with use of traditional, microbial and enzymatic methods. Iranian J. Fisheries Sci., 12(Summer): 79-94.

Nayeem, N. A., Pervin, K., Reza, M. S., Khan, M. N. A., Islam, M. N. and Kamal, M. 2010. Quality assessment of traditional semi-fermented fishery product (Chepa Sutki) of Bangladesh collected from the value chains. Bangladesh Res. Publication J., 4: 41-46.

Pearson, D. 1976. The Chemical Analysis of Food. Churchilli, New York, London. pp. 374-410.

Taniguchi, A. Y and Takano, K. 2007. Effects of protease and collagenase in the production of fish sauce using mature chum salmon (Oncorhynchus keta). J. World Aq., 38(2): 19-21.

Xu-Wei., Gang, Y., Xue-Chang, H., Xue, Y. and Yan, R. 2008 Biochemical changes associated with fast fermentation of squid processing by-products for low salt fish sauce. J. Food Chem., 107(4): 1597-1604

Zaman, M. Z., Abdulamir, A. S., Bakar, A. F., J. and Selamat, J. 2009. Microbiological, physicochemical and health impact of high level of biogenic amines in fish sauce. J. Appl. Sci., 6(6): 1199-1211. 